IRA-International Journal of Management \& Social Sciences

ISSN 2455-2267; Vol.06, Issue 01 (2017)

Pg. no. 104-108

Institute of Research Advances

http://research-advances.org/index.php/RAJMSS

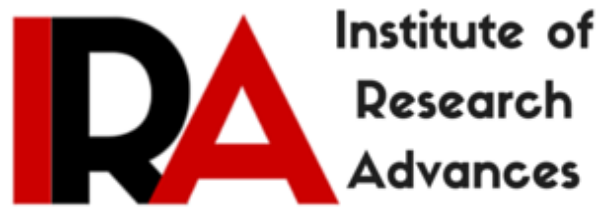

\title{
An Application of Logic in Everyday Life
}

\author{
Dr. Abdul Shakil \\ Associate Professor, \\ Department of Philosophy Addis Ababa University, Ethiopia.
}

Type of Review: Peer Reviewed.

DOI: http://dx.doi.org/10.21013/jmss.v6.n1.p14

\section{How to cite this paper:}

Shakil, A. (2017). An Application of Logic in Everyday Life. IRA-International Journal of Management \& Social Sciences (ISSN 2455-2267), 6(1), 104-108. doi:http://dx.doi.org/10.21013/jmss.v6.n1.p14

(C) Institute of Research Advances

(cc) EY-NC

This work is licensed under a Creative Commons Attribution-Non Commercial 4.0 International License subject to proper citation to the publication source of the work.

Disclaimer: The scholarly papers as reviewed and published by the Institute of Research Advances (IRA) are the views and opinions of their respective authors and are not the views or opinions of the IRA. The IRA disclaims of any harm or loss caused due to the published content to any party. 


\section{ABSTRACT}

This is an action research on "An Application of Logic in Everyday Life". Logic is an important area of study which can be applied in our day to day life activities. So it is fair enough to do an action research on an application of logical. Action research is known by many other names such as participatory research, collaborative inquiry, emancipatory research, action learning, and contextual action research. But all these kinds are variations on a theme. In other words, we can simply say that action research is "learning by doing." A group of people identify a problem, do something to resolve it, see how successful their efforts were, and if not satisfied, try again. Prof Kurt Lewin, a German psychologist, first coined the term 'action research' in his paper entitled, "Action Research and Minority Problems", published in 1946( Jagadish, 2012, p.108). Lewin is therefore known as the father of action research.

\section{Introduction}

Logic, on the other hand, may be defined as the science that evaluates arguments. All of us encounter arguments in our everyday life. We read arguments in books, magazines and newspapers, hear them on television, and formulate them when communicating with friends, parents, juniors and senior colleagues.

The aim of logic therefore is to develop a system of methods and principles that we may use as criteria for evaluating the arguments of others and as guides in constructing arguments of our own. Among the benefits to be expected from the study of logic is an increase in confidence that we are making sense when we criticize the arguments of others and when we advance arguments of our own. An argument, as it occurs in logic, is a group of statements, one or more of which (the premises) are claimed to provide support for, or reasons to believe, one of the others (the conclusion). All arguments may be placed in one of two basic groups: those in which the premises really do support the conclusion and those in which they do not, even though they are claimed to. The former are said to be good arguments (at least to that extent), the latter bad arguments. The purpose of logic, as the science that evaluates arguments, is thus to develop methods and techniques that allow us to distinguish good arguments from bad. As is apparent from the above definition, the term "argument" has a very specific meaning in logic. It does not mean, for example, a mere verbal fight, as one might have with one's parent, spouse, or friend. Let us examine the features of this definition in greater detail. First of all, an argument is a group of statements. A statement is sentence that is either true or false - in other words, typically a declarative sentence or a sentence component that could stand as a declarative sentence (Patrick, p.1). In short, we can say that logic is the study of methods and principles used to distinguish correct reasoning from incorrect one (Irving, p.3).It therefore has a great relevance in our day to day life and hence is very important area of conducting action research.

\section{Objective}

To assess the attitude, knowledge and application of logical learning among the students of Mechanical Engineering first year, section four of AAIT. The following are the other objectives of this action research:

- To find out the ways to teach logic in a better way so that the students can understand the value of this course to utilize in their practical life.

- To evaluate the interest of students in logic.

- To evaluate the outputs of the students and to carry those evaluations for reform and further teaching of the subject. 


\section{Research Questions}

Fifteen questions have been framed to assess the attitude, knowledge and application of logical reasoning (appendix 1). I have tried to find out the ways how we can teach logic to the students according to their interest so that they can utilize this knowledge in practical life. I have also tried to know what the students have achieved through this study.

\section{Limitation of the Study}

Due to the limitation of the time and resources, only 30 students of Mechanical Engineering first year, section four of AAIT could be assessed.

\section{Review of Literature}

There have been innumerous action researches in philosophy but I did not find any action research on logic. It would therefore be an important piece of action research in this domain.

\section{Methodology}

A. Sample

This action is a purposive (non-probabilistic) research based on the sample of 30 students of Mechanical Engineering, first year, and section four of AAIT. Therefore, the obtained results can be applied to these students only, it cannot be generalize.

\section{B. Instrument}

Questionnaire was prepared consisting of 15 questions. Likert type of scale was applied to get responses on each question.

\section{Data Analysis}

A Likert type scale responses were obtained from "strongly agree" to "strongly disagree" in five categories. Strongly agree was having weightage of 5 scores while strongly disagree was having the weightage of one score on each question. So the responses of 30 students were tabulated and total scores (weightage) and average score on each question was calculated.

\section{Ethical Considerations}

Participation was voluntary in nature. Participants have been assured that their identities and responses will be kept confidential and will be used for research purpose only.

\section{Results:}

\begin{tabular}{|l|l|l|l|}
\hline $\begin{array}{l}\text { Q. } \\
\text { No. }\end{array}$ & Questions & $\begin{array}{l}\text { Total } \\
\text { Scores of 30 } \\
\text { Respondents }\end{array}$ & $\begin{array}{l}\text { Average } \\
\text { Scores of 30 } \\
\text { Respondents }\end{array}$ \\
\hline 1. & $\begin{array}{l}\text { Logic can be applied as the subject of vital interest in } \\
\text { academic institutions of higher learning. }\end{array}$ & 4.46 \\
\hline 2. & $\begin{array}{l}\text { The study of logic provides the knowledge and skills needed } \\
\text { to construct good arguments of one's own and evaluate that of } \\
\text { others. }\end{array}$ & $\mathbf{1 3 5}$ & $\mathbf{4 . 5 0}$ \\
\hline 3. & $\begin{array}{l}\text { We apply logic for making correct reasoning and using } \\
\text { accurate language. }\end{array}$ & 128 & 4.26 \\
\hline 4. & $\begin{array}{l}\text { In broader sense, logic helps us to builds an attitude of batting } \\
\text { against bias and prejudices, superstitions and uncivilized } \\
\text { attitude. }\end{array}$ & 3.73 \\
\hline 5. & With the help of logic, we gain knowledge of methods and & 124 & 4.13 \\
\hline
\end{tabular}




\begin{tabular}{|c|c|c|c|}
\hline & $\begin{array}{l}\text { skills of constructing and evaluating arguments and hence } \\
\text { apply in our practical life. }\end{array}$ & & \\
\hline 6. & $\begin{array}{l}\text { Logic can help enlarge our thoughts and free them from the } \\
\text { tyranny of custom. }\end{array}$ & 115 & 3.83 \\
\hline 7. & $\begin{array}{l}\text { Training in logic builds on a foundation of basic reasoning } \\
\text { skills that helps to build a life on practical reasoning. }\end{array}$ & 118 & 3.93 \\
\hline 8. & $\begin{array}{l}\text { We can apply logic in recognizing similarities and differences } \\
\text { between patterns of reasoning while dealing with others in our } \\
\text { practical life. }\end{array}$ & 121 & 4.03 \\
\hline 9. & $\begin{array}{l}\text { We can apply logic in recognizing misunderstandings or } \\
\text { points of disagreement while arguing on any practical } \\
\text { problem. }\end{array}$ & 129 & 4.30 \\
\hline 10. & $\begin{array}{l}\text { Similar to the sciences, logic has indirect value to everyone } \\
\text { due to the effects it has on those who study it. }\end{array}$ & 111 & 3.70 \\
\hline 11. & $\begin{array}{l}\text { Study of logic will help us in making practical life more } \\
\text { fruitful and reasonable. }\end{array}$ & 126 & 4.20 \\
\hline 12. & $\begin{array}{l}\text { You must make yourself stay focused and make yourself work } \\
\text { at logic every day for few hours. }\end{array}$ & 93 & $3.10 * *$ \\
\hline 13. & $\begin{array}{l}\text { Introductory logic is a course that every student takes during } \\
\text { the first year of college. No other course will be as dedicated } \\
\text { to the task of understanding and sharpening analytical abilities } \\
\text { and skills in general; the benefits of doing this course-work } \\
\text { will show up throughout college career and beyond college as } \\
\text { well. }\end{array}$ & 115 & 3.83 \\
\hline 14. & $\begin{array}{l}\text { After learning the course of logic, we can apply the principles } \\
\text { of it to the areas of expertise such as engineering, journalism, } \\
\text { law etc. }\end{array}$ & 128 & 4.26 \\
\hline 15. & $\begin{array}{l}\text { We appreciate the study of logic because it makes us able to } \\
\text { be logical, rational, critical and systematical in each and every } \\
\text { walks of our practical life. }\end{array}$ & 133 & 4.43 \\
\hline
\end{tabular}

\section{Discussion and Analysis}

The maximum score 135 of 30 respondents has been obtained by question no.2, "The study of logic provides the knowledge and skills needed to construct good arguments of one's own and evaluate that of others"; while minimum score 93 of 30 respondents has been obtained by question no.12, "You must make yourself stay focused and make yourself work at logic every day for few hours" of this research." This research therefore finds that the respondents give maximum average score of 4.50 to the second question while question no.12 got minimum score of 3.10 of this questionnaire. It therefore confirms that though logic is an important domain to study to the concern students but they do not want to stay focused for few hours every day but most of the students concerned agree that the study of logic provides them the knowledge and skills needed to construct good arguments of one's own and evaluate that of others. It therefore has an important and fruitful role in day-to-day experiences. 


\section{Conclusion and Recommendations}

This research has presented an overview of action research on logic. Because as we know that the logical reasoning is an important tool to solve the problems we face in our day to day life activities. Details of a search tools were given as was an indication of the roles and ethics involved in the research. Further action research is needed to explore the potential for developing the ability of argumentation among the students that will enhance human interactions. We must therefore improve the techniques of teaching logic and be prepared to use action research techniques to better understand and utilize this research.

\section{References}

1. Jagadish R. Raiyani, Research Methodology: Theory and Techniques, New Century Publications, New Delhi, 2012.

2. Patrick J. Hurley, A Concise Introduction to Logic, 5th ed. Wadsworth Publishing Company, California, 1994.

3. ABL Group, Future Search Process Design, York University, Toronto, 1997.

4. Ortrun Zuber-Skerritt, ed. "Some Principles and Procedures for the Conduct of Action Research", New Directions in Action Research, Falmer Press, London, 1996.

5. Irving M. Copi, Carl Cohen, Introduction to Logic, 14th ed., Macmillan, 2010.

\section{Study Questionnaire}

\section{APPENDIX 1}

Please indicate your response to each statement by circling one of the following options: Strongly Agree (5), Agree (4), Do not know (3), Disagree (2), Strongly Disagree (1)

1. Logic can be applied as the subject of vital interest in academic institutions of higher learning.

2. The study of logic provides the knowledge and skills needed to construct good arguments of one's own and evaluate that of others.

3. We apply logic for making correct reasoning and using accurate language.

4. In broader sense, logic helps us to builds an attitude of batting against bias and prejudices, superstitions and uncivilized attitude.

5. With the help of logic, we gain knowledge of methods and skills of constructing and evaluating arguments and hence apply in our practical life.

6. Logic can help enlarge our thoughts and free them from the tyranny of custom.

7. Training in logic builds on a foundation of basic reasoning skills that helps to build a life on practical reasoning.

8. We can apply logic in recognizing similarities and differences between patterns of reasoning while dealing with others in our practical life.

9. We can apply logic in recognizing misunderstandings or points of disagreement while arguing on any practical problem.

10. Similar to the sciences, logic has indirect value to everyone due to the effects it has on those who study it.

11. Study of logic will help us in making practical life more fruitful and reasonable.

12. You must make yourself stay focused and make yourself work at logic every day for a few hours.

13. Introductory logic is a course that every student takes during the first year of college. No other course will be as dedicated to the task of understanding and sharpening analytical abilities and skills in general; the benefits of doing this course-work will show up throughout college career and beyond college as well.

14. After learning the course of logic, we can apply the principles of it to the areas of expertise such as engineering, journalism, law etc.

15. We appreciate the study of logic because it makes us able to be logical, rational, critical and systematical in each and every walks of our practical life. 